\title{
Release of dissolved organic nitrogen from Scenedesmus quadricauda (Chlorophyta) and Microcystis novacekii (Cyanobacteria)
}

\author{
Fumitaka Nagao ${ }^{1}$, Tatsuo Miyazaki ${ }^{2, *}$ \\ ${ }^{1}$ Laboratory of Marine Environmental Microbiology, Division of Applied Biosciences, Graduate School of Agriculture, \\ Kyoto University, Kyoto 606-8502, Japan \\ ${ }^{2}$ Marine Biosystems Research Center, Chiba University, Amatsu-Kominato, Awa-gun, Chiba-ken 299-5502, Japan
}

\begin{abstract}
We measured the time-course of dissolved organic nitrogen (DON) release and inorganic nitrogen assimilation in the freshwater phytoplankton Scenedesmus quadricauda (Turp.) Brébission and Microcystis novacekii (Kom.) Comp. by the ${ }^{15} \mathrm{~N}$ tracer method. The algae were cultivated under nitrogen-limited or -replete conditions. We estimated the total DON release, release of recently assimilated nitrogen (RANR) and net nitrogen assimilation (NNA), using ammonium chloride or sodium nitrate as the nitrogen source. In the ${ }^{15} \mathrm{~N}$ tracer incubation of $S$. quadricauda prior to $1 \mathrm{~h}$ and in $M$. novacekii prior to 3-6 h, minimal release of total DON was observed under the nitrogen-limited conditions. This result suggests that nitrogen-limited cells efficiently use incorporated nitrogen. Appreciable release of total DON was observed in the ${ }^{15} \mathrm{~N}$ incubation of nitrogen-replete S. quadricauda and M. novacekii. RANR in both nitrogen-limited and -replete algae was smaller than, and lagged behind, release of total DON, indicating that newly assimilated nitrogen was less easily released. NNA by nitrogen-limited $S$. quadricauda increased from the onset of the tracer incubation, showing that ambient nitrogen was needed for nitrogen-limited cells from the beginning of the incubation. Nitrogen-replete $S$. quadricauda showed no NNA during the first $1 \mathrm{~h}$ of the tracer incubation, suggesting that the alga did not require external nitrogen immediately after being transferred from nitrogen-replete conditions. This study shows that nitrogen release and assimilation are markedly affected by the nutritional states of the algae.
\end{abstract}

KEY WORDS: Ammonium · Nitrogen assimilation · Organic nitrogen release $\cdot$ Microcystis novacekii . Nitrate $\cdot$ Scenedesmus quadricauda

\section{INTRODUCTION}

Release of dissolved organic matter (DOM) by phytoplankton has been studied from various points of view: kinetics of DOM release (Fogg et al. 1965, Nalewajko et al. 1976, Lancelot 1979, Mague et al. 1980, Sellner 1981); relationships between DOM release and phytoplankton population density (Watt 1966, Anderson \& Zeutschel 1970, Thomas 1971, Berman \& HolmHansen 1974); and effects of ambient nutrient concen-

\footnotetext{
${ }^{*}$ Corresponding author. E-mail: myzkt@beige.ocn.ne.jp

trations (Smith et al. 1977, Giordano et al. 1994) and temperature (Watanabe 1980) on DOM release.

Despite many studies on DOM release, slightly contradictory results have emerged. For example, the relationship between the total primary production and the ratio of DOM release to primary production has been variously reported (Baines \& Pace 1991). Fogg et al. (1965), Anderson \& Zeutschel (1970) and Berman (1976) showed that primary production was inversely related to the ratio, whereas Lancelot (1979), Sellner (1981), Brock \& Clyne (1984) and Bell \& Kuparinen (1984) did not detect an inverse relation. In addition, the composition of the released compounds has been 
variously reported in different DOM-release studies. Watt (1969) and Fogg (1983) suggested that the released substances consist mainly of low molecular weight compounds, such as amino acids and early photosynthates. However, Nalewajko \& Schindler (1976), Chrost \& Faust (1983) and Sundh (1989) reported that released DOM is often dominated by compounds with high molecular weights. These discrepancies seem related to the nutritional and physiological states of the algae tested.

Release of organic nitrogen by phytoplankton may be influenced by the nitrogen demand and physiology of the algal cells, as was suggested by the studies on DOM release. Nitrogen is an important factor for cellular nutrition and physiology. Nitrogen-limited cells will not readily release organic nitrogen, because nitrogen is required for growth and maintenance of optimal cell conditions. On the contrary, nitrogen-replete cells are likely to release more organic nitrogen. Nitrogen release is related to nitrogen uptake by the phytoplankton (Bronk \& Glibert 1993, Flynn \& Berry 1999). Studies on the relationship between DON (dissolved organic nitrogen) release and the nitrogen states of algae will contribute to the clarification of phytoplankton dynamics and nitrogen cycling in aquatic environments.

In this study, we determined DON release from the freshwater phytoplankton Scenedesmus quadricauda (Chlorophyta) and Microcystis novacekii (Cyanobacteria), using the method for measurement of total nitrogen release, recently assimilated nitrogen release (RANR) and net nitrogen assimilation (NNA) (Nagao \& Miyazaki 1999). We used algae grown under different sets of nitrogen repletion, nitrogen limitation, nitrogen sources and light regimes, and we discuss the effects of nitrogen and light conditions on DON release.

Table 1. Summary of the precultivation and ${ }^{15} \mathrm{~N}$-tracer incubation of Scenedesmus quadricauda (Sq) and Microcystis novacekii (Mn). B: batch; C: chemostat; L: light; D: dark

\begin{tabular}{|c|c|c|c|c|c|c|}
\hline \multirow[t]{2}{*}{ Expt } & \multirow[t]{2}{*}{ Species } & \multicolumn{3}{|c|}{$\longrightarrow$ Preculture -} & \multicolumn{2}{|c|}{${ }^{15} \mathrm{~N}$ incubation } \\
\hline & & Culture & N-source & $\mathrm{N}: \mathrm{C}$ (atomic ratio) & Irradiance & N-source \\
\hline $1 \mathrm{~A}$ & $\mathrm{Sq}$ & $\mathrm{B}$ & $\mathrm{NH}_{4}^{+}$ & $0.185 \pm 0.002$ & $\mathrm{~L}$ & $\mathrm{NH}_{4}^{+}$ \\
\hline $1 \mathrm{~B}$ & $\mathrm{Sq}$ & $\mathrm{B}$ & $\mathrm{NH}_{4}^{+}$ & $0.180 \pm 0.002$ & $\mathrm{~L}$ & $\mathrm{NO}_{3}^{-}$ \\
\hline $2 \mathrm{~A}$ & $\mathrm{Sq}$ & $\mathrm{C}$ & $\mathrm{NH}_{4}^{+}$ & $0.075 \pm 0.001$ & $\mathrm{~L}$ & $\mathrm{NH}_{4}^{+}$ \\
\hline $2 \mathrm{~B}$ & $\mathrm{Sq}$ & $\mathrm{C}$ & $\mathrm{NH}_{4}^{+}$ & $0.068 \pm 0.001$ & $\mathrm{~L}$ & $\mathrm{NO}_{3}^{-}$ \\
\hline $2 \mathrm{C}$ & $\mathrm{Sq}$ & $\mathrm{C}$ & $\mathrm{NH}_{4}^{+}$ & $0.075 \pm 0.001$ & $\mathrm{D}$ & $\mathrm{NH}_{4}^{+}$ \\
\hline $2 \mathrm{D}$ & $\mathrm{Sq}$ & $\mathrm{C}$ & $\mathrm{NH}_{4}^{+}$ & $0.068 \pm 0.001$ & $\mathrm{D}$ & $\mathrm{NO}_{3}^{-}$ \\
\hline $3 \mathrm{~A}$ & $\mathrm{Sq}$ & $\mathrm{C}$ & $\mathrm{NO}_{3}^{-}$ & $0.078 \pm 0.003$ & $\mathrm{~L}$ & $\mathrm{NH}_{4}^{+}$ \\
\hline $3 \mathrm{~B}$ & $\mathrm{Sq}$ & $\mathrm{C}$ & $\mathrm{NO}_{3}^{-}$ & $0.078 \pm 0.003$ & $\mathrm{~L}$ & $\mathrm{NO}_{3}^{-}$ \\
\hline $4 \mathrm{~A}$ & $\mathrm{Mn}$ & $\mathrm{C}$ & $\mathrm{NH}_{4}^{+}$ & $0.101 \pm 0.003$ & $\mathrm{~L}$ & $\mathrm{NH}_{4}^{+}$ \\
\hline $4 \mathrm{~B}$ & $\mathrm{Mn}$ & $\mathrm{C}$ & $\mathrm{NH}_{4}^{+}$ & $0.101 \pm 0.000$ & $\mathrm{~L}$ & $\mathrm{NO}_{3}^{-}$ \\
\hline $4 \mathrm{C}$ & $\mathrm{Mn}$ & $\mathrm{C}$ & $\mathrm{NH}_{4}^{+}$ & $0.101 \pm 0.003$ & $\mathrm{D}$ & $\mathrm{NH}_{4}^{+}$ \\
\hline $4 \mathrm{D}$ & $\mathrm{Mn}$ & $\mathrm{C}$ & $\mathrm{NH}_{4}^{+}$ & $0.101 \pm 0.003$ & $\mathrm{D}$ & $\mathrm{NO}_{3}^{-}$ \\
\hline
\end{tabular}

\section{MATERIALS AND METHODS}

We used the green alga Scenedesmus quadricauda (Turp.) Brébission and the blue-green alga Microcystis novacekii (Kom.). S. quadricauda was isolated, maintained and is still available in our laboratory, and $M$. novacekii was kindly supplied by Dr M. Watanabe of Tsukuba Botanical Garden, National Science Museum, Japan (Tsukuba Algal Collection TAC 19).

We pre-cultivated Scenedesmus quadricauda in chemostats or batch cultures and Microcystis novacekii in chemostats in the Modified WC medium (Guillard \& Lorenzen 1972) containing $\mathrm{NH}_{4} \mathrm{Cl}$ or $\mathrm{NaNO}_{3}$ as the nitrogen source at $25^{\circ} \mathrm{C}$. Nitrogen concentrations in the supplied medium were $50 \mu$ g-at $\mathrm{N}$ $\mathrm{l}^{-1}$ in batch cultures, and $40 \mu \mathrm{g}$-at $\mathrm{N}^{-1}$ in chemostat cultures. Light was supplied at an irradiance of 150 mmol photons $\mathrm{m}^{-2} \mathrm{~s}^{-1}$ by cool-white fluorescent lamps (14:10 h light:dark cycle). The culture medium was continuously stirred by a magnetic bar and bubbled with air filtered through axenic membrane filters $(0.2 \mu \mathrm{m})$. All chemostats were maintained at a constant dilution rate $\left(0.3\right.$ to $\left.0.4 \mathrm{~d}^{-1}\right)$ for at least $7 \mathrm{~d}$ until the turbidity at $665 \mathrm{~nm}$ became constant (Watanabe \& Miyazaki 1996). N:C ratios (by atom) were $\sim 0.07$ for $S$. quadricauda and $\sim 0.10$ for $M$. novacekii, which were similar to the data used in Watanabe \& Miyazaki (1996). Batch cultures of S. quadricauda were carried out for $4 \mathrm{~d}$ until the late exponential phase, during which the growth rate was 1.4 to $1.5 \mathrm{~d}^{-1}$. N:C ratios of batch-cultured $S$. quadricauda $(\sim 0.183)$ were higher than those of chemostat-cultured $S$. quadricauda and the value (0.15) calculated from the Redfield ratio (Table 1). The cultivation conditions are listed in Table 1. Duplicate samples were removed at predetermined intervals for analysis.

Concentrations of ammonium and nitrate in the algal suspensions were determined according to the phenolhypochlorite method detailed in Sagi (1966) and the hydrazinium reduction method (Mullin \& Riley 1955), respectively. Concentrations of ammonium and nitrate under steady state in the chemostat cultures were below the detection limit, so algal cells were considered to be nitrogen-limited (Watanabe \& Miyazaki 1996).

Aliquots $(70 \mathrm{ml})$ of pre-cultivated algal suspension were dispensed into $100 \mathrm{ml}$ glass bottles for ${ }^{15} \mathrm{~N}$ incubation (Miyazaki et al. 1985). At the same time, we prepared samples incubated without added ${ }^{15} \mathrm{~N}$ as controls in each treatment. The measured value of ${ }^{15} \mathrm{~N}$ 
content was constant $(0.365 \%) .{ }^{15} \mathrm{NH}_{4} \mathrm{Cl}(99.3$ at \%) or $\mathrm{Na}^{15} \mathrm{NO}_{3}\left(99.4\right.$ at \%) $\left(90 \mu \mathrm{g}\right.$-at $\left.\mathrm{N} \cdot \mathrm{l}^{-1}\right)$ was added to the bottles. Light-incubated bottles were incubated at $25^{\circ} \mathrm{C}$ at an irradiance of $150 \mathrm{mmol}$ photons $\mathrm{m}^{-2} \mathrm{~s}^{-1}$. Dark-incubated bottles were wrapped in aluminum foil. The incubation conditions are listed in Table 1. After incubation, samples were fixed with formalin (final conc. $0.2 \%$ ). In the present study, TDONR (total dissolved organic nitrogen release) was not observed or was minimal at the initial phase of the ${ }^{15} \mathrm{~N}$ incubation using chemostat-precultivated algae, even though the samples were fixed with formalin, indicating minimal artificial release occurs. If artificial release was caused by the formalin treatment, more TDONR would have been observed during this initial phase. This indicates that artificial release due to fixation was minimal or negligible in the present study. We used formalin to fix samples to allow greater precision with the incubation time. If we had not used formalin, the incubation time would have become more inaccurate.

Fixed samples were filtered through Whatman GF/C filters (4 to $5 \mu$-at $\mathrm{N}$ ). $\mathrm{NaCl}$ was added to filtrates to increase the salinity, and the filtrates were processed with the ion retardation column according to the method of Bronk \& Gilbert (1991) with the modification described in Nagao \& Miyazaki (1999). Nitrogen contents and ${ }^{15} \mathrm{~N}$ at \% in algal particles on filters and in filtrates were determined with a quadrupole mass spectrometer (Anelva TE-150) (Miyazaki et al. 1985).

We estimated TDONR (total DON released during the ${ }^{15} \mathrm{~N}$ incubation), RANR (release of DON produced from DIN [dissolved inorganic nitrogen] assimilated into cells during the ${ }^{15} \mathrm{~N}$ incubation) and NNA (gross nitrogen assimilation minus total released nitrogen during the ${ }^{15} \mathrm{~N}$ incubation) by the calculation method of Nagao \& Miyazaki (1999) (see Appendix 1 for summary of the estimation methods). Equations for the calculation of DON release and DIN assimilation are based on the mass balance of nitrogen among DIN, DON and PON (particulate organic nitrogen). Release of nitrogen assimilated before the ${ }^{15} \mathrm{~N}$ incubation is discerned from the release of nitrogen assimilated during the ${ }^{15} \mathrm{~N}$ incubation.

\section{RESULTS}

\section{DON release from Scenedesmus quadricauda}

Release of DON and NNA were examined in the light in nitrogen-replete Scenedesmus quadricauda. We prepared $S$. quadricauda by batch pre-cultivation with ammonium. We considered the batch-cultured $S$. quadricauda as nitrogen-replete, because the S. quadricauda cells had cellular $\mathrm{N}$ : C ratios (0.18 to
$0.185), 2.4$ to 2.8 times higher than nitrogen-limited cells cultured in chemostats (0.068 to 0.075$)$ (Table 1$)$. In the ammonium incubation (Expt 1A) of nitrogenreplete $S$. quadricauda, a TDONR of $0.38 \mu$ g-at $\mathrm{N} \mu \mathrm{g}$-at $\mathrm{N}^{-1}$ was observed at $1 \mathrm{~h}$ (Fig. 1A). In the nitrate incubation (Expt 1B), TDONR observed was $0.28 \mu \mathrm{g}$-at $\mathrm{N}$ $\mu \mathrm{g}$-at $\mathrm{N}^{-1}$ at $1 \mathrm{~h}$ (Fig. 1B). For both ammonium and nitrate incubations (Fig. 1A,B) TDONR was observed to increase slightly from 1 until $12 \mathrm{~h}$. RANR in the ammonium incubation was nearly zero during the incubation (Expt 1A; Fig. 1A). RANR in the nitrate incubation was almost zero until $3 \mathrm{~h}$ and then increased to $0.2 \mu \mathrm{g}$-at $\mathrm{N} \mu \mathrm{g}$-at $\mathrm{N}^{-1}$ at $12 \mathrm{~h}$ (Expt $1 \mathrm{~B}_{\text {; }}$ Fig. 1B). The percentages of RANR to TDONR at $12 \mathrm{~h}$ were $2.5 \%$ in the ammonium incubation and $51 \%$ in the nitrate-incubation (Table 2). NNA at $1 \mathrm{~h}$ was zero in both the ammonium and nitrate incubations. After $1 \mathrm{~h}$, NNA increased. NNA was higher than TDONR after $4 \mathrm{~h}$ in the ammonium and nitrate incubations.

TDONR, RANR and NNA were measured in the nitrogen-limited Scenedesmus quadricauda precultivated with ammonium in chemostats in the light (Expts 2A and 2B; Fig. 2A,B). TDONR was lower at 1 to $3 \mathrm{~h}$ (Fig. 2A,B) compared with the nitrogen-replete $S$. quadricauda (Fig. 1). RANR was nearly zero in the ammonium incubation, while it was zero until $3 \mathrm{~h}$ and increased to $0.24 \mu \mathrm{g}$-at $\mathrm{N} \mathrm{\mu g}$-at $\mathrm{N}^{-1}$ in the nitrate incu-
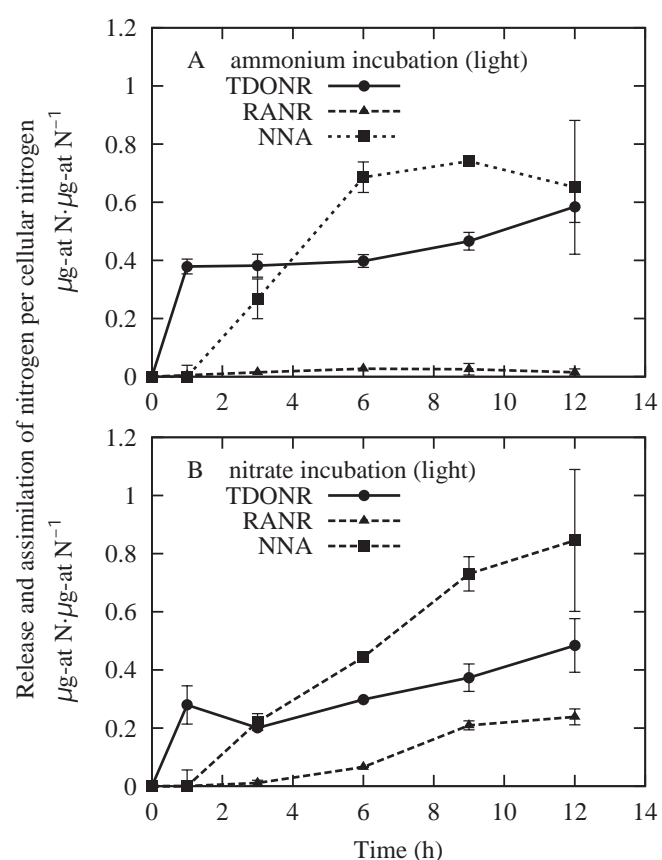

Fig. 1. Cellular N specific DON release and DIN assimilation by nitrogen-replete Scenedesmus quadricauda in the light during ${ }^{15} \mathrm{~N}$-tracer incubation $\left({ }^{15} \mathrm{NH}_{4} \mathrm{Cl}\right.$ or $\mathrm{Na}^{15} \mathrm{NO}_{3}: 90 \mu \mathrm{g}$-at $\left.\mathrm{N} \cdot \mathrm{l}^{-1}\right)$. The alga was prepared by cultivation under an excess supply of ammonium $\left(50 \mu \mathrm{g}\right.$-at $\left.\mathrm{N} \cdot \mathrm{l}^{-1}\right)$ in batch. (A) Incubation in ammonium (Expt 1A). (B) Incubation in nitrate (Expt 1B) 

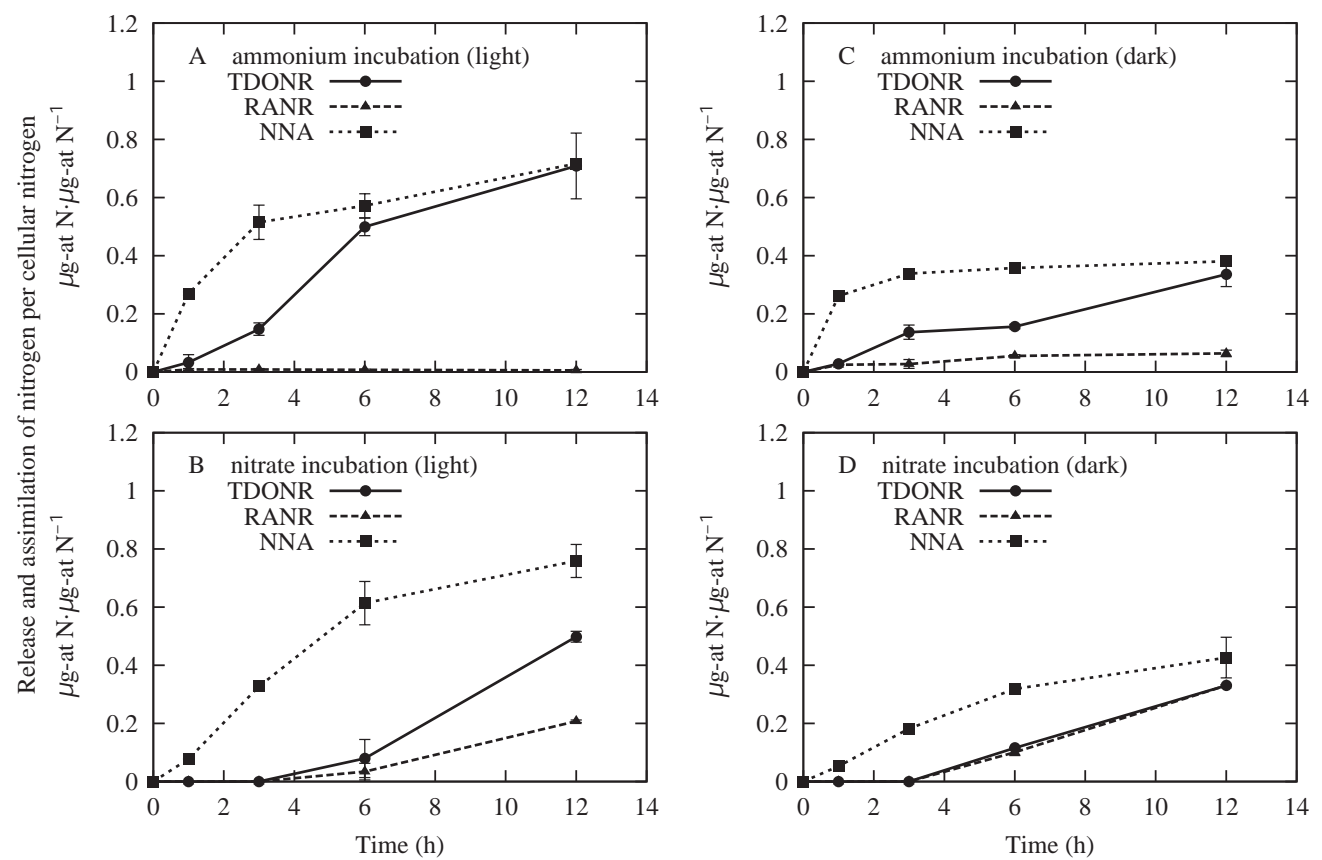

Fig. 2. Cellular N specific DON release and DIN assimilation by nitrogen-limited Scenedesmus quadricauda during ${ }^{15} \mathrm{~N}$-tracer incubation $\left({ }^{15} \mathrm{NH}_{4} \mathrm{Cl}\right.$ or $\mathrm{Na}^{15} \mathrm{NO}_{3}: 90 \mu \mathrm{g}$-at $\left.\mathrm{N} \cdot \mathrm{l}^{-1}\right)$. The alga was prepared by cultivation under a supply of ammonium (40 $\mu \mathrm{g}$-at $\mathrm{N} \cdot \mathrm{l}^{-1}$ ) in chemostats. (A) Incubation in ammonium and in the light (Expt 2A). (B) Incubation in nitrate and in the light (Expt 2B).

(C) Incubation in ammonium and in the dark (Expt 2C). (D) Incubation in nitrate and in the dark (Expt 2D)

bation. The percentage of RANR to TDONR at $12 \mathrm{~h}$ was $0.8 \%$ when ammonium was supplied as the nitrogen source in the ${ }^{15} \mathrm{~N}$ incubation (Expt 2A; Fig. 2A) and $42 \%$ when nitrate was supplied (Expt 2B; Fig. 2B) (Table 2). NNA increased with time in the ammonium (Expt 2A; Fig. 2A) and the nitrate incubations (Expt 2B; Fig. 2B) (Fig. 2). This NNA increase was similar to that in Expt 1 using nitrogen-replete $S$. quadricauda, except that NNA in nitrogen-replete $S$. quadricauda was zero at $1 \mathrm{~h}$. NNA at $12 \mathrm{~h}$ reached $0.71-0.72 \mu \mathrm{g}$-at $\mathrm{N} \mu \mathrm{g}$-at $\mathrm{N}^{-1}$.

In the dark incubations for nitrogen-limited Scenedesmus quadricauda, TDONR showed a gradual increase (Expts 2C and 2D; Fig. 2C,D). TDONR at $12 \mathrm{~h}$ was $0.34 \mu \mathrm{g}$-at $\mathrm{N} \mu \mathrm{g}$-at $\mathrm{N}^{-1}$ in the ammonium incubation and $0.33 \mu \mathrm{g}$-at $\mathrm{N} \mu \mathrm{g}$-at $\mathrm{N}^{-1}$ in the nitrate incubation. RANR was nearly constant (less than $0.64 \mu \mathrm{g}$-at $\mathrm{N} \mu g$-at $\mathrm{N}^{-1}$ ) in the ammonium incubation. RANR in

Table 2. Percentages of the recently assimilated nitrogen release to total DON release (RANR/TDONR $\times 100)$ and TDONR to gross nitrogen assimilation (TDONR/GNA $\times 100$ ) in ${ }^{15} \mathrm{~N}$-tracer incubation of Scenedesmus quadricauda (Sq) and Microcystis novacekii $(\mathrm{Mn})$. Data values were calculated from duplicate samples. B: batch; C: chemostat; L: light; D: dark

\begin{tabular}{|c|c|c|c|c|c|c|c|c|}
\hline \multirow[t]{2}{*}{ Expt } & \multirow{2}{*}{ Species } & \multicolumn{2}{|c|}{ Preculture } & \multicolumn{2}{|c|}{${ }^{15} \mathrm{~N}$ incubation } & \multirow{2}{*}{$\begin{array}{c}\text { RANR/TDONR (\%) } \\
12 \mathrm{~h}\end{array}$} & \multicolumn{2}{|c|}{ TDONR/GNA (\%) } \\
\hline & & Culture & N-source & Irradiance & $\mathrm{N}$-source & & $3 \mathrm{~h}$ & $12 \mathrm{~h}$ \\
\hline $1 \mathrm{~A}$ & $\mathrm{Sq}$ & B & $\mathrm{NH}_{4}^{+}$ & $\mathrm{L}$ & $\mathrm{NH}_{4}^{+}$ & $2.5 \pm 2.7$ & $59.3 \pm 7.8$ & $48.9 \pm 10.8$ \\
\hline $1 \mathrm{~B}$ & $\mathrm{Sq}$ & B & $\mathrm{NH}_{4}^{+}$ & $\mathrm{L}$ & $\mathrm{NO}_{3}^{-}$ & $51.1 \pm 13.2$ & $47.3 \pm 3.4$ & $37.4 \pm 9.4$ \\
\hline $2 \mathrm{~A}$ & $\mathrm{Sq}$ & $\mathrm{C}$ & $\mathrm{NH}_{4}{ }^{+}$ & $\bar{L}$ & $\mathrm{NH}_{4}^{+}$ & $0.8 \pm 0.6$ & $22.3 \pm 3.7$ & $49.4 \pm 4.6$ \\
\hline $2 \mathrm{~B}$ & $\mathrm{Sq}$ & $\mathrm{C}$ & $\mathrm{NH}_{4}^{+}$ & $\mathrm{L}$ & $\mathrm{NO}_{3}^{-}$ & $41.7 \pm 2.1$ & $0.0 \pm 0.0$ & $41.6 \pm 2.5$ \\
\hline $2 \mathrm{C}$ & $\mathrm{Sq}$ & $\mathrm{C}$ & $\mathrm{NH}_{4}^{+}$ & $\mathrm{D}$ & $\mathrm{NH}_{4}^{+}$ & $19.4 \pm 4.9$ & $28.6 \pm 4.3$ & $46.7 \pm 3.7$ \\
\hline $2 \mathrm{D}$ & $\mathrm{Sq}$ & $\mathrm{C}$ & $\mathrm{NH}_{4}^{+}$ & $\mathrm{D}$ & $\mathrm{NO}_{3}^{-}$ & $98.7 \pm 2.5$ & $0.0 \pm 0.0$ & $44.2 \pm 4.7$ \\
\hline $3 \mathrm{~A}$ & $\mathrm{Sq}$ & $\mathrm{C}$ & $\mathrm{NO}_{3}^{-}$ & $\mathrm{L}$ & $\mathrm{NH}_{4}^{+}$ & $33.4 \pm 20.7$ & $14.0 \pm 7.8$ & $48.6 \pm 8.9$ \\
\hline $3 B$ & $\mathrm{Sq}$ & $\mathrm{C}$ & $\mathrm{NO}_{3}^{-}$ & $\mathrm{L}$ & $\mathrm{NO}_{3}^{-}$ & $42.3 \pm 2.4$ & $11.6 \pm 2.2$ & $42.4 \pm 1.6$ \\
\hline $4 \mathrm{~A}$ & Mn & $\mathrm{C}$ & $\mathrm{NH}_{4}{ }^{+}$ & $\mathrm{L}$ & $\mathrm{NH}_{4}^{+}$ & $99.5 \pm 15.2$ & $4.7 \pm 1.3$ & $25.9 \pm 1.9$ \\
\hline $4 \mathrm{~B}$ & $\mathrm{Mn}$ & $\mathrm{C}$ & $\mathrm{NH}_{4}^{+}$ & $\mathrm{L}$ & $\mathrm{NO}_{3}^{-}$ & - & $5.1 \pm 5.8$ & $25.5 \pm 18.3$ \\
\hline $4 \mathrm{C}$ & $\mathrm{Mn}$ & $\mathrm{C}$ & $\mathrm{NH}_{4}^{+}$ & $\mathrm{D}$ & $\mathrm{NH}_{4}^{+}$ & $100.5 \pm 23.4$ & $4.5 \pm 4.7$ & $33.4 \pm 4.6$ \\
\hline $4 \mathrm{D}$ & $\mathrm{Mn}$ & $\mathrm{C}$ & $\mathrm{NH}_{4}^{+}$ & $\mathrm{D}$ & $\mathrm{NO}_{3}^{-}$ & - & $0.1 \pm 0.1$ & $2.6 \pm 2.4$ \\
\hline
\end{tabular}


the nitrate incubation showed almost the same trend as the TDONR. The ratios of RANR to TDONR at $12 \mathrm{~h}$ were $19 \%$ in the ammonium incubation and $98.0 \%$ in the nitrate incubation (Table 2). NNA in the dark increased with time. NNA at $12 \mathrm{~h}$ was 0.38 and $0.43 \mu \mathrm{g}$-at $\mathrm{N} \mu \mathrm{g}$-at $\mathrm{N}^{-1}$ in the ammonium and nitrate incubations, respectively.

TDONR, RANR and NNA in the light incubations for Scenedesmus quadricauda, which was chemostatprecultivated with nitrate as the nitrogen source (Expt 3 ; Fig. 3), were similar to those in Expt 2 using ammoniumprecultivated, nitrogen-limited cells (Fig. 2).

\section{DON release from Microcystis novacekii}

Minimal TDONR appeared at 1 to $3 \mathrm{~h}$ in the light incubation of nitrogen-limited Microcystis novacekii precultivated with ammonium in chemostats (Expts $4 \mathrm{~A}$ and $4 \mathrm{~B}$, Fig. 4A,B). TDONR increased after $3 \mathrm{~h}$. This TDONR change until $3 \mathrm{~h}$ was similar to the trends observed during the initial phase of Expts 2 to 4 using nitrogen-limited Scenedesmus quadricauda. In Expts $4 \mathrm{~A}$ and $4 \mathrm{~B}$, RANR was almost the same as TDONR. This result contrasted with those of Expts $2 \mathrm{~A}$ and $2 \mathrm{~B}$, where RANR by ammonium-precultivated, nitrogenlimited $S$. quadricauda was almost zero. NNA by am-
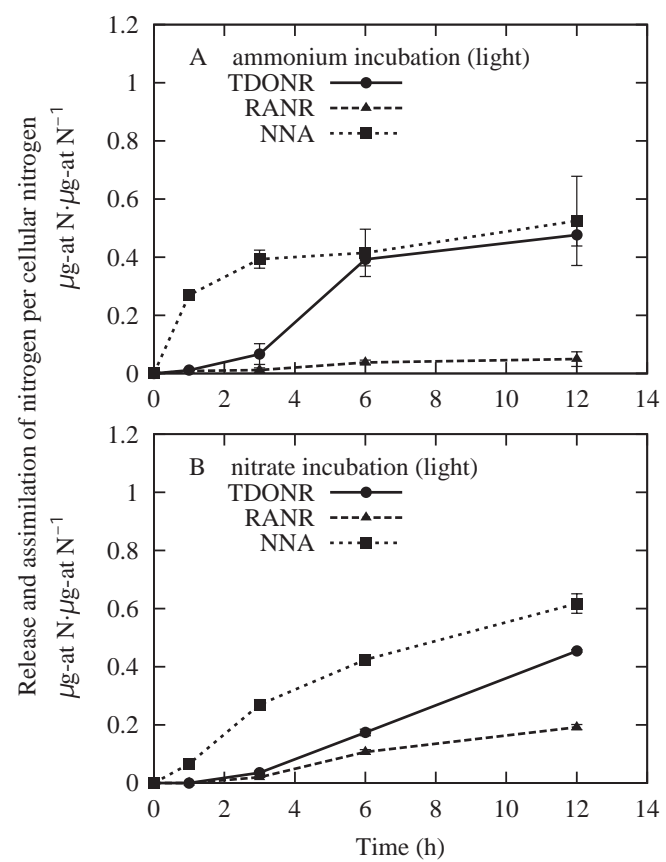

Fig. 3. Cellular N specific DON release and DIN assimilation by nitrogen-limited Scenedesmus quadricauda in the light during ${ }^{15} \mathrm{~N}$-tracer incubation $\left({ }^{15} \mathrm{NH}_{4} \mathrm{Cl}\right.$ or $\mathrm{Na}^{15} \mathrm{NO}_{3}$ : $90 \mu$-at $\mathrm{N}^{-1}$ ). The alga was prepared by cultivation under a supply of nitrate $\left(40 \mu \mathrm{g}\right.$-at $\left.\mathrm{N}^{-1}\right)$ in chemostats. (A) Incubation in ammonium (Expt 3A). (B) Incubation in nitrate (Expt 3B)
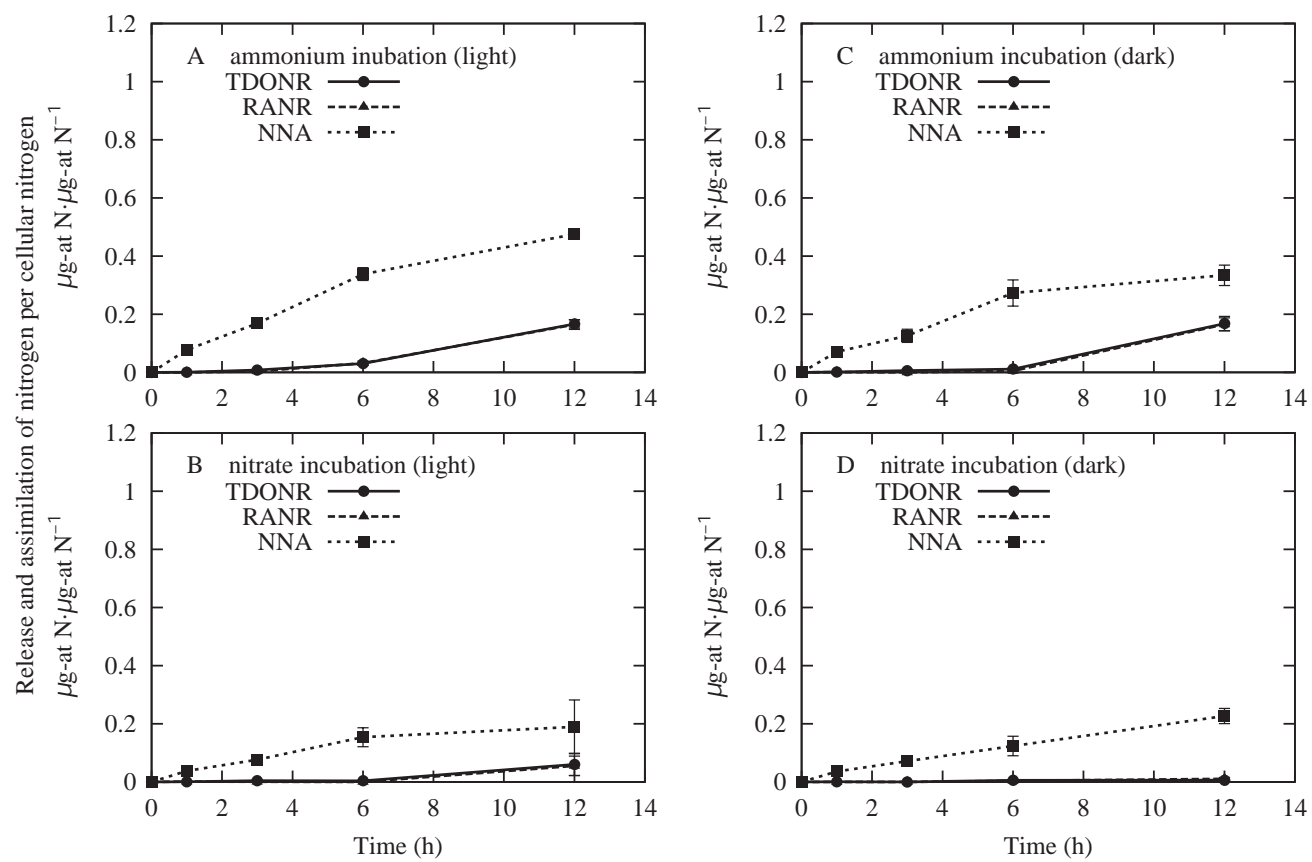

Fig. 4. Cellular N specific DON release and DIN assimilation by nitrogen-limited Microcystis novacekii during ${ }^{15} \mathrm{~N}$-tracer incubation $\left({ }^{15} \mathrm{NH}_{4} \mathrm{Cl}\right.$ or $\mathrm{Na}^{15} \mathrm{NO}_{3}: 90 \mu \mathrm{g}$-at $\left.\mathrm{N} \mathrm{I}^{-1}\right)$. The alga was prepared by cultivation under a supply of ammonium (40 $\mu \mathrm{g}$-at $\mathrm{N} \mathrm{l}^{-1}$ ) in chemostats. (A) Incubation in ammonium and in the light (Expt 4A). (B) Incubation in nitrate and in the light (Expt 4B). (A) Incubation in ammonium and in the dark (Expt 4C). (B) Incubation in nitrate and in the dark (Expt 4D) 
monium-precultivated, nitrogen-limited $M$. novacekii was lower than that by ammonium-limited $S$. quadricauda (Fig. 2).

In the dark, TDONR by ammonium-precultivated, nitrogen-limited Microcystis novacekii (Expts 4C and 4D; Fig. 4C,D) did not appear until $6 \mathrm{~h}$ during the ${ }^{15} \mathrm{~N}$ ammonium incubation (Expt $4 \mathrm{C}_{i}$ Fig. $4 \mathrm{C}$ ) and not until $12 \mathrm{~h}$ in the ${ }^{15} \mathrm{~N}$-nitrate incubation (Expt 4D; Fig. 4D). TDONR in the dark was lower than results for Scenedesmus quadricauda and $M$. novacekii incubated under light conditions. NNA in the dark by $M$. novacekii linearly increased during the tracer incubations and was lower than values in the light for $S$. quadricauda and M. novacekii.

\section{DISCUSSION}

\section{The possibility of an artificial DON release}

Several factors such as the containment of samples in bottles, fixation (Shimura et al. 1978) and filtration (Vogel et al. 1978) may result in the artificial releases of DON (Bronk \& Glibert 1994). Assimilation of DIN and/or DON by bacteria present in samples might make it difficult to estimate exactly the DON release from algae (Li 1990, Stockner et al. 1990, Hoch \& Kirchman 1995). Re-assimilation of released DON by the algal cells themselves may lead to an underestimation of DON release. Therefore, it is necessary to assess the effects of these factors on the DON release measurements.

We incubated the sample algae in glass incubation bottles. After incubation, we fixed the samples with formalin $(0.2 \%)$ and filtered them gravitationally with glass-fiber filters for DON-release measurements. Previous studies have reported that fixation with formalin and rough filtration caused an anomalous release of DOM (Shimura et al. 1978, Vogel et al. 1978). Kirchman et al. (1989) found that even gentle gravity filtration increased the release of dissolved free amines. In the present study, TDONR was not observed or was minimal at the initial phase of the ${ }^{15} \mathrm{~N}$ incubation (Figs. 2 to 4) using chemostat-precultivated algae, even though the samples were fixed and filtered. This indicates that any artificial release by containment, fixation and filtration was negligible, though further studies will be needed to confirm this negligible artificial release.

Uptake of DIN and/or DON by bacteria might alter the estimation of DON release. When ammonium is used as a nitrogen source, bacteria sometimes take up significant amounts of ammonium from the sample water when both algae and bacteria are present (Li 1990, Hoch \& Kirchman 1995). This uptake might change the ambient nitrogen concentrations and would affect the estimation of DON release. In this study, we used axenic samples, and thus, excluding contamination, there was no or minimal uptake by bacteria. Even if bacteria were present in the samples, most bacteria would pass into filtrates, since we used Whatman GF/C filters to collect particles larger than $1.2 \mathrm{~mm}$ in diameter. If so, nitrogen incorporated by bacteria would be estimated as DON release. Ammonium uptake by bacteria might lead to an overestimation of DON release. In the present study, TDONR was nearly zero even at the initial phase of the ${ }^{15} \mathrm{~N}$ incubation using chemostat-precultivated algae when the ammonium concentration was higher (Figs. 2 \& 4). Therefore, we consider that nitrogen uptake by bacteria had minimal influence on the estimation of DON release. However, it is known that phytoplankton can take up DON (Collos et al. 1992, Bronk \& Glibert 1993, Flynn \& Berry 1999), and as we did not measure the reassimilation of DON by the algae, the release of DON may be underestimated.

Flynn \& Berry (1999) explained the difference in DON release between low and high nitrogen systems, considering the equilibrium of organic nitrogen between release leakage and transport back into algae. In the present tracer incubation, total system nitrogen was about $100 \mu \mathrm{g}$-at $\mathrm{N}^{-1}$. According to Flynn \& Berry (1999), the DON released would be less than $5 \%$ of the total system nitrogen at $100 \mu \mathrm{g}$-at $\mathrm{N}^{-1}$. The percentage in the present study was 0 to $20 \%$ before $3 \mathrm{~h}$. At later times, a higher percentage was observed. These values were not necessarily comparable with the data of Flynn \& Berry (1999). This is in part because carbon would become limiting at later times, and the system did not necessarily attain the equilibrium of organic nitrogen as mentioned in Flynn \& Berry (1999). Though the present incubation systems were not necessarily equilibrated in the same way as in Flynn \& Berry (1999), we can discuss the relative difference in nitrogen release among algae with different nutrient status.

\section{DON release and nitrogen assimilation}

Scenedesmus quadricauda precultivated in nitrogen-replete conditions excreted DON (TDONR) from the beginning of the tracer incubation (Fig. 1). On the contrary, $S$. quadricauda precultivated in nitrogenlimited conditions released minimal DON (TDONR) at $1 \mathrm{~h}$ during the tracer incubation (Figs. $2 \& 3$ ). TDONR increased after 1 to $3 \mathrm{~h}$. Similarly, Microcystis novacekii grown in nitrogen-limited conditions released minimal DON (TDONR) at $1 \mathrm{~h}$ during the tracer incubation (Fig. 4). This result is contrary to the observa- 
tions by Marlow et al. (1989) that phytoplankton under stress such as nutrient limitation increase DOM release. The smaller TDONR by the nitrogen-limited algae suggests that the algae suppress TDONR to fulfill the cellular nitrogen demand.

In the present study, RANR by Microcystis novacekii precultivated in nitrogen-limited conditions was larger at $6 \mathrm{~h}$ or later under the supply of ammonium than that of nitrate in the tracer incubations. On the contrary, RANR by Scenedesmus quadricauda precultivated in nitrogen-limited conditions was smaller at $6 \mathrm{~h}$ or later under ammonium supply than under nitrate supply in the tracer incubations. This result shows that planktonic algae do not necessarily release recently assimilated nitrogen more readily under ammonium supply than nitrate supply, and it suggests that RANR depends on the species of nitrogen source and algae.

The ratios of RANR to TDONR at $12 \mathrm{~h}$ were mostly smaller in Scenedesmus quadricauda than in Microcystis novacekii when the algae were precultivated in nitrogen-limited conditions. This suggests that $S$. quadricauda releases more DON stored before the tracer incubations compared with $M$. novacekii. Mague et al. (1980) proposed the hypothesis that DOC (dissolved organic carbon) is released when pools of DOC are saturated. Flynn \& Butler (1986) suggested that the release of DOM was due to overflow from DOM pools. If the nitrogen was released in a similar way, the difference in the ratio of RANR to TDONR between $S$. quadricauda and M. novacekii may be due to the difference in the cellular DON pool size.

We can only speculate on the components of previously and recently assimilated nitrogen, as we did not directly measure them. Mague et al. (1980) suggested that exudates originating from carbon recently taken up into cells were rich in low-molecular compounds. Wiebe \& Smith (1986) stated that actively growing phytoplankton excreted mostly low-molecular compounds. Compounds released from recently assimilated nitrogen in the present study might thus be mainly composed of low-molecular compounds such as amino acids. In contrast, Bronk \& Glibert (1991) speculated that cell components discharged by cell lysis had higher molecular weights. DON released from previously assimilated nitrogen might be of higher molecular weight compounds compared with that from recently assimilated compounds, as some of the previously assimilated nitrogen might have been synthesized into components with higher molecular weights.

NNA after $1 \mathrm{~h}$ in tracer incubations reflected the difference between nitrogen sources. In Scenedesmus quadricauda, NNA in the ${ }^{15} \mathrm{~N}$-ammonium incubation was higher than that in the ${ }^{15} \mathrm{~N}$-nitrate incubation (Figs. 2 \& 3). In Microcystis novacekii, NNA after $1 \mathrm{~h}$ of tracer incubations was higher in the ${ }^{15} \mathrm{~N}$-ammonium incubation than in the ${ }^{15} \mathrm{~N}$-nitrate incubation. One of the possible reasons for these results may be that ammonium is more reduced than nitrate. Energy cost for amino-acid synthesis from inorganic nitrogen compounds seems lower for ammonium than for nitrate (Thompson et al. 1989, Levasseur et al. 1993), so ammonium may be taken up more readily; however, Larsson et al. (1985) showed that there was no difference in the levels of reduced pyridine nucleotides after the addition of ammonium or nitrate in the presence of carbon dioxide.

The difference in nitrogen source did not lead to a difference in NNA after $12 \mathrm{~h}$ tracer incubation in Scenedesmus quadricauda $\left(0.72 \mu \mathrm{g}\right.$-at $\mathrm{N} \mu \mathrm{g}$-at $\mathrm{N}^{-1}$ for ammonium; 0.72 for $\mu g$-at $\mathrm{N} \mu \mathrm{g}$-at $\mathrm{N}^{-1}$ for nitrate). Total inorganic carbon measured with the nearinfrared method in the incubation medium became zero after $6 \mathrm{~h}$. Carbon would be limiting after $6 \mathrm{~h}$. After $6 \mathrm{~h}$, nitrogen assimilation would be limited by carbon, and thus the difference in NNA during the initial phase of the incubation would disappear.

Chan \& Campbell (1978) found that the release of nitrogen increased in the light in a Canadian Shield lake. In the present study, light increased the TDONR in both Scenedesmus quadricauda and Microcystis novacekii. This increase was observed in both the ${ }^{15} \mathrm{~N}$ ammonium and ${ }^{15} \mathrm{~N}$-nitrate tracer incubations (Figs. 2 to 4). In the dark, algae cannot synthesize organic carbon through photosynthesis. Since algae cannot newly produce organic carbon which is required for the synthesis of organic nitrogen compounds, a lower release of DON would be expected in dark incubations.

TDONR by nitrogen-limited Microcystis novacekii was lower than that by nitrogen-limited Scenedesmus quadricauda (Figs. 2 to 4 ). The ratio of TDONR to gross nitrogen assimilation $($ GNA $=$ TDONR + NNA) was lower in M. novacekii than in S. quadricauda after 3 and $12 \mathrm{~h}$ incubations in the presence of tracer ammonium (Table 2). This suggests that $M$. novacekii utilizes the assimilated ammonium-nitrogen more effectively. This more effective assimilation by $M$. novacekii could be related to the lower half-saturation constant of ammonium uptake $\left(K_{\mathrm{m}}\right)$ compared with $S$. quadricauda (Watanabe \& Miyazaki 1996). NNA in the nitrogenlimited conditions was lower in $M$. novacekii than in $S$. quadricauda. This lower NNA may lead to a lower maximum uptake ( $\left.V_{\max }\right)$ of ammonium in $M$. novacekii. Thus, the results of nitrogen release and assimilation can be used to partly explain the $V_{\max }$ and $K_{\mathrm{m}}$ values, which in turn can be used to assess the competitive interaction between $M$. novacekii and $S$. quadricauda (Watanabe \& Miyazaki 1996), though some changes in the kinetic parameters may occur because of the change in the rate of transport due to feedback processes (Flynn 1998). 
Bronk \& Ward (2000) and Slawyk et al. (2000) discussed the sources of DON release. The present calculation assumes that DIN is assimilated into organic nitrogen compounds of algal cells whether the compounds are dissolved or components of cell structure and that DON released originates from the organic nitrogen compounds in the cells. We did not use TCA to separate DON into component DONs. We considered the mass balance of tracers among DIN, DON and PON. The present NNA was assumed to correspond to the net DIN uptake measured in Dugdale \& Goering (1967). The summed values of TDONR and NNA will be considered to correspond to the gross DIN uptake (Slawyk et al. 1998).
The present results show that nitrogen release was influenced by the nitrogen status of the algae. DON was released more readily by nitrogen-replete algae than by nitrogen-limited algae. The patterns of release were related to the assimilation of the nitrogen. Differences between Microcystis novacekii and Scenedesmus quadricauda were observed. The differences would affect the competitive advantage of the algae under differing environmental nitrogen sources. It is necessary to study the relationship between DON release and ecological interactions of algae to obtain clearer insights into phytoplankton competitive interactions.

Appendix 1. Calculation of DON release and DIN assimilation (Nagao \& Miyazaki 1999)

Equations for the calculation of DON release and DIN assimilation are based on the mass balance of nitrogen among DIN, DON and PON.

When DON release and assimilation occur simultaneously, during $\delta t$ (time difference between $t$ and $t_{1}: t_{1}=t+\delta t$ ), the mass balance of total nitrogen $\left({ }^{14} \mathrm{~N}+{ }^{15} \mathrm{~N}\right)$ is described as:

$$
\mathrm{TDONR}+\mathrm{PON}_{t_{1}}=\mathrm{PON}_{t}+\mathrm{GNA}
$$

where TDONR is the total DON released during $\delta t$. $\mathrm{PON}_{t_{1}}$ and $\mathrm{PON}_{t}$ are PON at $t_{1}$ and $t$, respectively. GNA (gross nitrogen assimilation) is the gross (released + unreleased) nitrogen assimilated during $\delta t$.

The mass balance of ${ }^{15} \mathrm{~N}$ is described by:

$$
\begin{aligned}
& A_{\mathrm{PON}_{t}} \cdot \mathrm{PON}_{t}+A_{\mathrm{DIN}} \cdot \mathrm{GNA}= \\
& \quad A_{\mathrm{PON}_{t_{1}}} \cdot \mathrm{PON}_{t_{1}}+A_{\mathrm{DON}_{t_{1}}} \cdot \mathrm{DON}_{t_{1}}-A_{\mathrm{DON}_{t}} \cdot \mathrm{DON}_{t}
\end{aligned}
$$

where $A_{\mathrm{PON}_{t}}$ and $A_{\mathrm{PON}_{t_{1}}}$ are the ${ }^{15} \mathrm{~N}$ at $\%$ of PON at $t$ and $t_{1}$, respectively. $A_{\text {DIN }}$ is the ${ }^{15} \mathrm{~N}$ at $\%$ of DIN. DON $t_{1}$ and DON are DON at $t_{1}$ and $t$, respectively. $A_{\mathrm{DON}_{t_{1}}}$ and $A_{\mathrm{DON}_{t}}$ are the ${ }^{15} \mathrm{~N}$ at $\%$ of DON at $t_{1}$ and $t$, respectively. We assume that nitrogen taken up is converted to PON and DON.

TDONR is expressed as:

$$
\mathrm{TDONR}=\mathrm{DON}_{t_{1}}-\mathrm{DON}_{t}
$$

From Eqs. (A1), (A2) and (A3), GNA and TDONR are calculated as follows:

$$
\mathrm{GNA}=\frac{A_{\mathrm{DON}_{t}}-A_{\mathrm{PON}_{t_{1}}}}{A_{\mathrm{DON}_{t}}-A_{\mathrm{DIN}}} \times \mathrm{PON}_{t_{1}}-\frac{A_{\mathrm{DON}_{t_{1}}}-A_{\mathrm{DON}_{t}}}{A_{\mathrm{DON}_{t}}-A_{\mathrm{DIN}}} \times
$$

$$
\mathrm{DON}_{t_{1}}+\frac{A_{\mathrm{PON}_{t}}-A_{\mathrm{DON}_{t}}}{A_{\mathrm{DON} t}-A_{\mathrm{DIN}}} \times \mathrm{PON}_{t}
$$

and

$$
\begin{aligned}
\mathrm{TDONR}= & \frac{A_{\mathrm{DIN}_{\mathrm{N}}}-A_{\mathrm{PON}_{t 1}}}{A_{\mathrm{DON}_{t}}-A_{\mathrm{DIN}}} \cdot \mathrm{PON}_{t_{1}}-\frac{A_{\mathrm{DON}_{t_{1}}}-A_{\mathrm{DON}_{t}}}{A_{\mathrm{DON}_{t}}-A_{\mathrm{DIN}}} . \\
& \mathrm{DON}_{t_{1}}+\frac{A_{\mathrm{PON} t}-A_{\mathrm{DIN}}}{A_{\mathrm{DON} t}-A_{\mathrm{DIN}}} \cdot \mathrm{PON}_{t}
\end{aligned}
$$

We define NNA (net nitrogen assimilation) as:

$$
\text { NNA }=\text { GNA }- \text { TDONR }
$$

TDONR is composed of RANR (recently assimilated nitrogen release: release of DON produced from DIN assimilated during $\delta t$ ) and PANR (previously assimilated nitrogen release: nitrogen assimilated before $t$ and released during $\delta t$ ). Thus, we have:

$$
\mathrm{TDONR}=\mathrm{RANR}+\mathrm{PANR}
$$

The mass balance of ${ }^{15} \mathrm{~N}$ present in TDONR is described by:

$$
\begin{aligned}
& A_{\mathrm{DIN}} \cdot \mathrm{RANR}+A_{\mathrm{PON} t} \cdot \mathrm{PANR}= \\
& A_{\mathrm{DON}_{t_{1}}} \cdot \mathrm{DON}_{t_{1}}-A_{\mathrm{DON} t} \cdot\left(\mathrm{DON}_{t_{1}}-\mathrm{TDONR}\right)
\end{aligned}
$$

From Eqs. (A7) and (A8), RANR may be calculated as follows:

$$
\mathrm{RANR}=\frac{A_{\mathrm{DON}_{t}}-A_{\mathrm{PON}_{t}}}{A_{\mathrm{DIN}}-A_{\mathrm{PON} t}} \cdot \mathrm{TDONR}+\frac{A_{\mathrm{DON}_{1}}-A_{\mathrm{DON}_{t}}}{A_{\mathrm{DIN}}-A_{\mathrm{PON} t}} \cdot \mathrm{DON}_{t_{1}}
$$

Acknowledgements. We thank Profs O. Maeda and K. Fujii for their encouragement during this study. We also thank T. Watanabe for his helpful comments on the cultivation of Scenedesmus quadricauda and Microcystis novacekii. We are grateful to Dr C. P. Norman for reading and correcting the manuscript. This work was supported in part by grants-in-aid from CREST (Core Research for Evolutional Science and Technology) of the Japan Science and Technology Corporation and from the Agricultural Upland Development Association.

\section{LITERATURE CITED}

Anderson GC, Zeutschel RP (1970) Release of dissolved organic matter by marine phytoplankton in coastal and offshore areas of northern Pacific Ocean. Limnol Oceanogr 15:402-407

Baines SB, Pace ML (1991) The production of dissolved organic matter by phytoplankton and its importance to bacteria: patterns across marine and freshwater systems. Limnol Oceanogr 36:1078-1090 
Bell RT, Kuparinen J (1984) Assessing phytoplankton and bacterioplankton production during early spring in Lake Erken, Sweden. Appl Environ Microbiol 48:1221-1230

Berman T (1976) Release of dissolved organic matter by photosynthesizing algae in Lake Kinneret, Israel. Freshw Biol 6:13-18

Berman T, Holm-Hansen O (1974) Release of photo-assimilated carbon as dissolved organic matter by marine phytoplankton. Mar Biol 28:305-310

Brock TD, Clyne J (1984) Significance of algal excretory products for growth of epilimnetic bacteria. Appl Environ Microbiol 47:731-734

Bronk DA, Glibert PM (1991) A ${ }^{15} \mathrm{~N}$ tracer method for the measurement of dissolved organic nitrogen release by phytoplankton. Mar Ecol Prog Ser 77:171-182

Bronk DA, Glibert PM (1993) Application of a ${ }^{15} \mathrm{~N}$ tracer method to the study of dissolved organic nitrogen uptake during spring and summer in Chesapeake Bay. Mar Biol 115:501-508

Bronk DA, Glibert PM (1994) The fate of the missing ${ }^{15} \mathrm{~N}$ differs among marine systems. Limnol Oceanogr 39:189-195

Bronk DA, Ward BB (2000) Magnitude of dissolved organic nitrogen release relative to gross nitrogen uptake in marine systems. Limnol Oceanogr 45:1879-1883

Bronk DA, Glibert PM, Ward BB (1994) Nitrogen uptake, dissolved organic nitrogen release, and new production. Science 265:1843-1846

Chan YK, Campbell NER (1978) Phytoplankton uptake and excretion of assimilated nitrate in a small Canadian Shield lake. Appl Environ Microbiol 35:1052-1060

Chrost RJ, Faust MA (1983) Organic carbon release by phytoplankton: its composition and utilization by bacterioplankton. J Plankton Res 5:477-493

Collos Y, Doler G, Biermann I (1992) Production of dissolved organic nitrogen during uptake of nitrate by Synedra planctonica: implications for estimates of new production in the oceans. J Plankton Res 14:1025-1029

Dugdale RC, Goering JJ (1967) Uptake of new and regenerated forms of nitrogen in primary productivity. Limnol Oceanogr 12:196-206

Flynn KJ (1998) Estimation of kinetic parameters for the transport of nitrate and ammonium into marine phytoplankton. Mar Ecol Prog Ser 169:13-28

Flynn KJ, Berry LS (1999) The loss of organic nitrogen during marine primary production may be significantly overestimated when using ${ }^{15} \mathrm{~N}$ substrates. Proc R Soc Lond Ser B Biol Sci 266:641-647

Flynn KJ, Butler I (1986) Nitrogen sources for the growth of marine microalgae: role of dissolved free amino acids. Mar Ecol Prog Ser 34:281-304

Fogg GE (1983) The ecological significance of extracellular products of phytoplankton photosynthesis. Bot Mar 26: $3-14$

Fogg GE, Nalewajko C, Watt WD (1965) Extracellular products of phytoplankton photosynthesis. Proc R Soc Lond Ser B Biol Sci 162:517-534

Giordano M, Davis JS, Bowes G (1994) Organic carbon release by Dunaliella salina (Chlorophyta) under different growth conditions of $\mathrm{CO}_{2}$, nitrogen, and salinity. J Phycol 30:249-257

Guillard RRL, Lorenzen CJ (1972) Yellow-green algae with chlorophyllide $C$. J Phycol 8:10-14

Hoch MP, Kirchman DL (1995) Ammonium uptake by heterotrophic bacteria in the Delaware estuary and adjacent coastal waters. Limnol Oceanogr 40:886-897

Kirchman DL, Keil RG, Wheeler PA (1989) The effect of amino acids on ammonium utilization and regeneration by het- erotrophic bacteria in the subarctic Pacific. Deep-Sea Res 36:1763-1776

Lancelot C (1979) Gross excretion rates of natural marine phytoplankton and heterotrophic uptake of excreted products in the southern North Sea, as determined by short-term kinetics. Mar Ecol Prog Ser 1:179-186

Larsson M, Olsson T, Larsson CM (1985) Distribution of reducing power between photosynthetic carbon and nitrogen assimilation in Scenedesmus. Planta 164:246-253

Levasseur ME, Thompson PA, Harrison PJ (1993) Physiological acclimation of marine phytoplankton to different nitrogen sources. J Phycol 29:587-595

Li WKW (1990) Particles in 'particle-free' seawater growth of ultraphytoplankton and implications for dilution experiments. Can J Fish Aquat Sci 47:1258-1268

Mague TH, Friberg E, Hughes DJ, Morris I (1980) Extracellular release of carbon by marine phytoplankton; a physiological approach. Limnol Oceanogr 25:262-279

Marlow IT, Rogers LJ, Smith AJ (1989) Extent and nature of extracellular organic production by the marine cocolithophorid Hymenomonas carterae. Mar Biol 100:381-391

Miyazaki T, Honjo Y, Ichimura S (1985) Applicability of the stable isotope method using ${ }^{13} \mathrm{C}$ and ${ }^{15} \mathrm{~N}$ simultaneously to the estimation of carbon and nitrogen assimilation in a eutrophic, freshwater lake, Lake Nakanuma, Japan. Arch Hydrobiol 102:355-365

Mullin JB, Riley JP (1955) The spectrophotometric determination of nitrate in natural waters, with particular reference to sea water. Anal Chim Acta 12:464-480

Nagao F, Miyazaki T (1999) A modified ${ }^{15} \mathrm{~N}$ tracer method and new calculation for estimating release of dissolved organic nitrogen by freshwater planktonic algae. Aquat Microb Ecol 16:309-314

Nalewajko C, Schindler DW (1976) Primary production, extracellular release, and heterotrophy in two lakes in the ELA, northwestern Ontario. J Fish Res Bd Can 33:219-226

Nalewajko C, Dunstall TG, Shear H (1976) Kinetics of extracellular release in axenic algae and in mixed algal-bacterial cultures: significance in estimation of total (gross) phytoplankton excretion rates. J Phycol 12:1-5

Sagi T (1966) Determination of ammonia in sea water by the indophenol method and its application to coastal and offshore waters. Oceanogr Mag 18:43-51

Sellner KG (1981) Primary productivity and the flux of dissolved organic matter in several marine environments. Mar Biol 65:101-112

Shimura S, Yamaguchi Y, Aruga Y, Fujita Y, Ichimura S (1978) Extracellular release of photosynthetic products by a pelagic blue-green alga Trichodesmium thiebautii. J Oceanogr Soc Jpn 34:181-188

Slawyk G, Raimbault P, Garcia N (1998) Measuring gross uptake of ${ }^{15} \mathrm{~N}$-labeled nitrogen by marine phytoplankton without particulate matter collection: evidence of $\operatorname{low}^{15} \mathrm{~N}$ losses to the dissolved organic nitrogen pool. Limnol Oceanogr 43:1734-1739

Slawyk G, Raimbault P, Garcia N (2000) Use of ${ }^{15} \mathrm{~N}$ to measure dissolved organic nitrogen release by marine phytoplankton (reply to comment by Bronk and Ward). Limnol Oceanogr 45:1884-1886

Smith WO Jr, Barber RT, Huntsman SA (1977) Primary production off the coast of Northwest Africa: excretion of dissolved organic matter and its heterotrophic uptake. DeepSea Res 24:35-47

Stockner JG, Klut ME, Cochlan WP (1990) Leaky filters: a warning to aquatic ecologists. Can J Fish Aquat Sci 47: 16-23

Sundh I (1989) Characterization of phytoplankton extracellu- 
lar products (PDOC) and their subsequent uptake by heterotrophic organisms in a mesotrophic forest lake. J Plankton Res 11:463-486

Thomas JP (1971) Release of dissolved organic matter from natural populations of marine phytoplankton. Mar Biol 11: 311-323

Thompson PA, Levasseur ME, Harrison PJ (1989) Light-limited growth on ammonium vs. nitrate: What is the advantage for marine phytoplankton? Limnol Oceanogr 34: 1014-1024

Vogel SL, Frisch HL, Gotham IJ (1978) Qualitative assay of dissolved amino acids and sugars excreted by Chlamydomonas reinhardtii (Chlorophyceae) and Euglena gracilis (Euglenophyceae). J Phycol 14:403-406

Watanabe T, Miyazaki T (1996) Maximum ammonium uptake

Editorial responsibility: William Li,

Dartmouth, Nova Scotia, Canada rates of Scenedesmus quadricauda (Chlorophyta) and Microcystis novacekii (Cyanobacteria) grown under nitrogen limitation and implications for competition. J Phycol 32:243-249

Watanabe Y (1980) A study of the excretion and extracellular products of natural phytoplankton in Lake Nakanuma, Japan. Int Rev Ges Hydrobiol 65:809-834

Watt WD (1966) Release of dissolved organic material from the cells of phytoplankton populations. Proc R Soc Lond Ser B Biol Sci 164:521-551

Watt WD (1969) Extracellular release of organic matter from two freshwater diatoms. Ann Bot 33:427-437

Wiebe WJ, Smith DF (1977) Direct measurement of dissolved organic carbon release by phytoplankton and incorporation by microheterotrophs. Mar Biol 42:213-223

Submitted: June 15, 2001; Accepted: December 27, 2001 Proofs received from author(s): March 13, 2002 